\title{
Long-term outcomes in children with chronic kidney disease stage 5 over the last 40 years
}

\author{
Dominika Adamczuk, Maria Roszkowska-Blaim
}

Department of Pediatrics and Nephrology, Medical University of Warsaw, Warsaw, Poland

Submitted: 1 May 2015

Accepted: 15 June 2015

Arch Med Sci 2017; 13, 3: 635-644

DOI: https://doi.org/10.5114/aoms.2017.67283

Copyright $\odot 2017$ Termedia \& Banach

\section{Abstract}

Introduction: We evaluated outcomes in children with chronic kidney disease stage 5 (CKD 5) treated in the first pediatric dialysis unit in Poland during 1973-2012.

Material and methods: The retrospective analysis included 208 children with CKD 5 undergoing renal replacement therapy (RRT), stratified into four decades of treatment: 1973-1982, 1983-1992, 1993-2002, and 2003-2012. Results: The most common causes of CKD 5 included glomerulonephritis in $27.4 \%$ and pyelonephritis secondary to urinary tract anomalies in $25.5 \%$ of children. Among 208 children, 172 (82.7\%) survived and 17.3\% died. Kidney transplantation (KTX) was performed in $47.6 \%$ of children, including pre-emptive KTx in $1.92 \%$ of children. Chronic dialysis was continued in $34.1 \%$ of children, and RRT was withdrawn in $1 \%$. The overall mortality rate was 6.2 per 100 patient-years, and 3 -year survival was $83.9 \%$. The highest mortality rate of 23.4 per 100 patient-years was observed among children in whom RRT was initiated in 1973-1982, with subsequent reduction of the mortality rate to 4.5 and 2.1 per 100 patient-years in 1993-2002 and 1983-1992 respectively. No deaths were noted after 2002. Cardiovascular problems were the most common cause of death, found in $36.1 \%$ of patients $(p<0.01)$. Identified risk factors for mortality included young age, low residual diuresis, anemia at the time of RRT initiation, and hypertriglyceridemia and hypoalbuminemia during RRT. Conclusions: In years 1973-2012 significant improvement in prognosis among children with CKD 5 was achieved. Identified predictors of mortality included young age at initiation of RRT, low residual diuresis, anemia and hypertriglyceridemia.

Key words: end-stage renal disease, survival, children, risk factors, renal replacement therapy.

\section{Introduction}

Advances in the treatment of chronic kidney disease (CKD) in the second half of the $20^{\text {th }}$ century resulted in significantly improved survival of patients with end-stage renal disease (ESRD) [1, 2]. According to the Australia and New Zealand Dialysis and Transplant Registry (ANZDATA), the mortality rate among children with ESRD decreased from 11 per 100 patient-years in 1963-1972 to 1.7 per 100 patient-years in 1983-1992 [1]. While infectious complications were the major cause of mortality among children with ESRD in the 1970s and 1980s, cardiovascular problems are currently the most common cause of death, found in $35-50 \%$ of fatal cases $[1,3,4]$. Among children undergoing dialysis therapy, survival contin-

\author{
Corresponding author: \\ Dominika Adamczuk PhD \\ Department of Pediatrics \\ and Nephrology \\ Medical University of Warsaw \\ 63a Zwirki i Wigury St \\ 02-091 Warsaw, Poland \\ Phone: +48 3179735 \\ E-mail: d.adamczuk@gmail. \\ com
}


ues to increase although at a lower rate, with the European Renal Association-European Dialysis and Transplant Association (ERA-EDTA) registry data indicating an increase in 2-year survival during the last two decades of the $20^{\text {th }}$ century by about $3 \%$ (from $90.9 \%$ to $94.2 \%$ ) [3], and the North American Pediatric Renal Transplant Cooperative Study (NAPRTCS) showing an increase in 2-year survival by $2 \%$ (from $90.7 \%$ to $92.7 \%$ ) in 1992-2007 [5, 6].

The aim of the study was to evaluate outcomes, including causes and risk factors for mortality, in children with ESRD treated in the first pediatric dialysis unit in Poland.

\section{Material and methods}

Our retrospective analysis included 208 children (91 girls and 117 boys) with CKD 5 in whom renal replacement therapy (RRT) was initiated in 19732012. The analysis was stratified into four decades of treatment depending on the year of RRT initiation, 1973-1982 ( $1^{\text {st }}$ decade, $\left.n=42\right), 1983-1992$ ( $2^{\text {nd }}$ decade, $\left.n=84\right), 1993-2002$ ( $3^{\text {rd }}$ decade, $n=54$ ), and 2003-2012 (4 $4^{\text {th }}$ decade, $n=28$ ). Mortality rates were analyzed in four age groups, $<5$ years, 5-9 years, 10-14 years, and $\geq 15$ years of age. Based on the available medical records, we evaluated age at the diagnosis of CKD (glomerular filtration rate (GFR) $<60 \mathrm{ml} / \mathrm{min} / 1.73 \mathrm{~m}^{2}$ ), cause of CKD, age at the initiation of RRT, RRT modalities used, and concomitant diseases. In addition, we evaluated the following parameters during selection for RRT and at the end of follow-up: (1) clinical variables including body height, body mass, and body mass index (BMI) expressed as standard deviation score (SDS), GFR estimated using the Schwartz formula, residual diuresis, use of erythropoiesis-stimulating agents (ESA), presence of arterial hypertension (defined as blood pressure $>95^{\text {th }}$ percentile for gender, age, and height, or the use of antihypertensive drugs), and left ventricular hypertrophy (diagnosed based on electrocardiography and/or echocardiography); and (2) biochemical parameters including blood hemoglobin $(\mathrm{Hb})$ level and serum urea $(U)$, creatinine (Creat), total protein (TP), albumin (Alb), total cholesterol (Chol), triglycerides (TG), calcium (Ca), and phosphorus (P) levels. The end of follow-up was defined as patient transfer to another dialysis unit (e.g., to an adult dialysis center or newly created regional pediatric dialysis units), kidney transplantation, or death. Causes of CKD 5 and mortality were categorized according to the pediatric ERA-EDTA registry [3]. The study was approved by the Bioethics Committee at the Medical University of Warsaw (approval no. 30/2008).

\section{Statistical analysis}

Normally distributed data are shown as mean values \pm standard deviation (SD), and non-nor- mally distributed data are shown as medians and ranges. Significance of differences between mean values of normally distributed variables in two independent groups was evaluated using Student's $t$ test for independent samples, and Student's $t$ test for paired samples when the groups were related to each other. The Mann-Whitney $U$ test was used for non-normally distributed variables in independent groups, and the Wilcoxon test for related groups. Univariate analysis of variance (ANOVA) was used to compare mean values between three or more groups with normal variable distribution, and the Kruskal-Wallis test was used for three or more groups with skewed variable distribution. The Pearson $\chi^{2}$ test was used to compare proportions in groups. Survival curves were estimated using the Kaplan-Meier method. Relative risk (RR) of mortality and 95\% confidence intervals (CI) were calculated using the Cox proportional hazard model. Statistical analyses were performed using the Statistica 9.0 software (Statsoft). $P<0.05$ was considered statistically significant.

\section{Results}

First pediatric hemodialysis (HD) treatment program in Poland was started in the Department of Pediatric Nephrology at the Medical University of Warsaw on May 3, 1973. Ten years later (Jan 3, 1983), continuous ambulatory peritoneal dialysis (CAPD) was introduced, and automatic peritoneal dialysis (ADO) was used from 1994 [7].

Mean age at the time of CKD diagnosis was $6.48 \pm 4.60$ years (range: $0-15.6$ years), and mean age at the initiation of RRT was $10.52 \pm 4$.40 years, with no significant differences between decades of the study period (Table I). Median time from the diagnosis of CKD to the initiation of RRT was 2.33 years. This time was shortest in 1973-1982 and was found to be significantly reduced $(p<0.05)$ compared to the second and third decades of the study period. The most common causes of CKD in the study population were glomerulonephritis and pyelonephritis secondary to urinary tract anomalies. In 1973-1982, glomerulonephritis was a significantly more common $(p<0.05)$ cause of CKD compared to later decades of the study period, in which the most common cause of ESRD was pyelonephritis.

Median duration of dialysis therapy was 1.83 years (range: 0.2-16.3), and the overall experience of our center was 508 patient-years of dialysis therapy during the 40-year study period. Hemodialysis (HD) was the initial RRT modality and the most commonly used treatment until 1992. In 1973-1982, HD was used significantly more frequently $(p<0.001)$ compared to the next decades. Between 1973 and 1980, HD was performed using a Kolff spiral dialysis machine and 


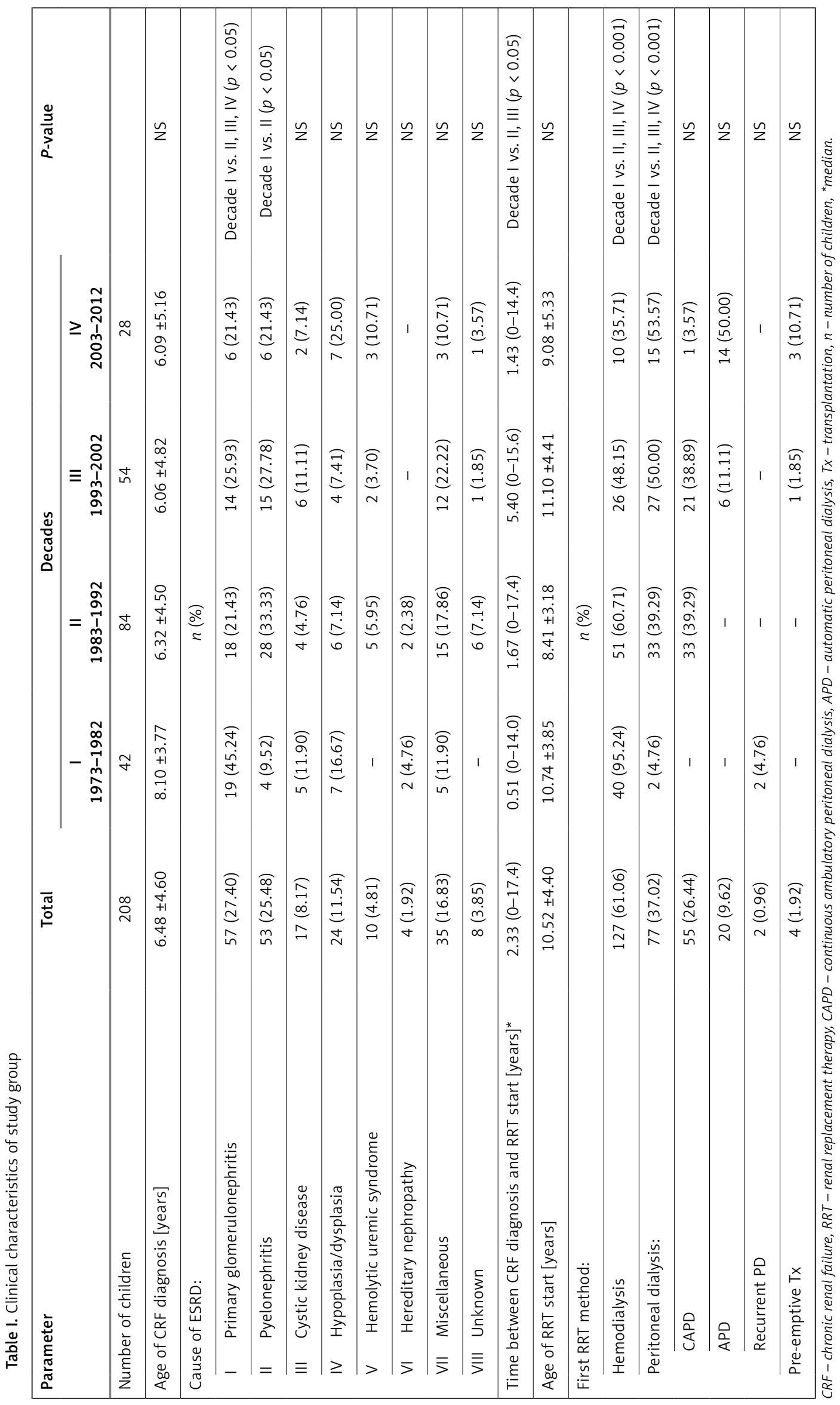


arteriovenous Scribner fistula. The next used dialyzers were plate Nycotron dialyzers, and Scribner fistulas were replaced with Cimino-Brescia arteriovenous fistulas, which resulted in a smaller loss of blood. The first peritoneal dialysis was undertaken on 3.01.1973 using the Travenol System (Baxter). Since 1983, chronic peritoneal dialysis has been used with growing frequency, initially as continuous ambulatory peritoneal dialysis (CAPD) and since the 1990s also as automatic peritoneal dialysis (APD).

Among 208 children undergoing RRT in 19732012, 172 (82.69\%) patients survived and 36 (17.31\%) died. Kidney transplantation was performed in 99 (47.6\%) children, including 4 patients who received a preemptive renal transplant from a living related donor. The rate of renal transplantations after 1983 was significantly higher ( $p<0.0001)$ compared to 1973-1982, when only $11.9 \%$ of children were treated with kidney transplantation (Figure 1). Twenty (9.61\%) children were transferred to other newly formed regional pediatric dialysis units in Poland, 43 (20.67\%) were transferred to adult dialysis units, and seven continue to receive RRT in our unit. The RRT was discontinued in 2 children, including one boy with kidney and liver polycystic disease due to lack of adequate vascular access for HD, and another one with hemolytic-uremic syndrome in whom renal function improved after 8 months of RRT.

\section{Analysis of mortality among children with CKD 5}

Mean age at the time of death was $11.83 \pm 5.14$ years. Overall, the mortality rate during the 40year study period was 6.2 per 100 patient-years, and 3 -year survival was $83.9 \%$. The highest mortality rate of 23.4 per 100 patient-years was found among children who began RRT in 1973-1982, with subsequent reduction of the mortality rate in 1983-1992 and 1993-2002 to 4.5 and 2.1 per 100 patient-years, respectively. As shown in Figure $2 \mathrm{~A}$, 3-year survival in the first three decades of the study period was $51.9 \%, 86.7 \%$, and $96.4 \%$, respectively.

When we analyzed mortality in different age groups, the highest death rate $(7 / 21$ children, $33.3 \%$ ) was found among those who began RRT below 5 years of age, significantly higher $(p<0.05)$ compared to the age groups of 10-14 years and $\geq 15$ years $(14.3 \%$ and $3.5 \%$, respectively; Figure 2 B). Survival among the youngest children differed significantly $(p<0.05)$ compared to that among children in whom RRT was initiated at the age of 10-14 years or $\geq 15$ years.

In the analysis of mortality in relation to the cause of CKD 5, the highest mortality (41.2\%) was found among children in the category of miscellaneous renal diseases. Mortality in this group was significantly higher $(p<0.05)$ compared to children with glomerulonephritis (15.09\%) and pyelonephritis (6.12\%). Among children who died, miscellaneous diseases were the cause of CKD in $14 / 36$ (38.9\%) patients, including amyloidosis in 6 children (of these, 5 had idiopathic juvenile arthritis and one had disseminated tuberculosis).

Concomitant disease was found in $33.3 \%$ of children who died, and the proportion of patients with concomitant diseases increased in subsequent decades of the follow-up period (Table II).

Among 36 children who died, 29 were treated with HD and 7 were treated with chronic perito-

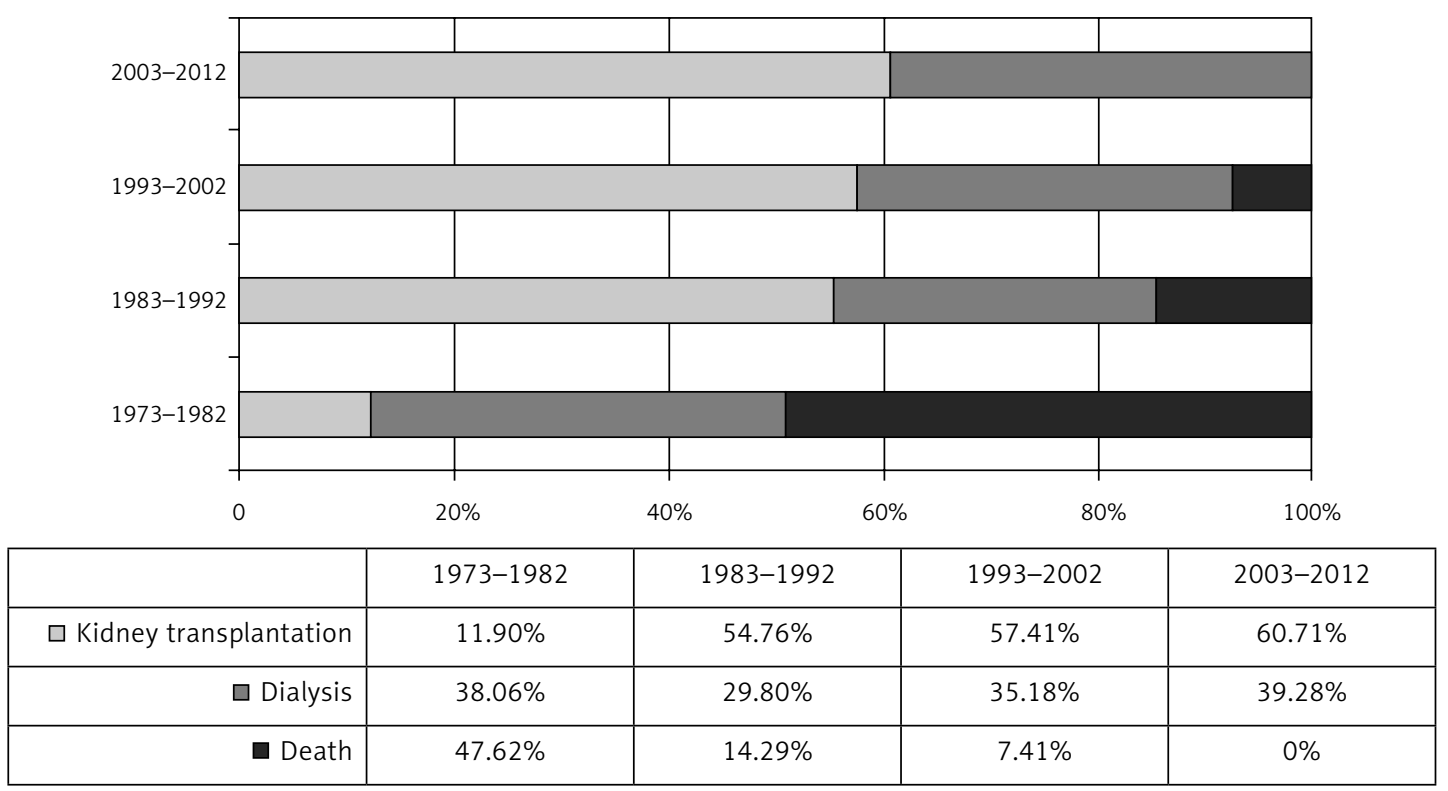

Figure 1. Outcomes of children treated with RRT in years 1973-2012 
A

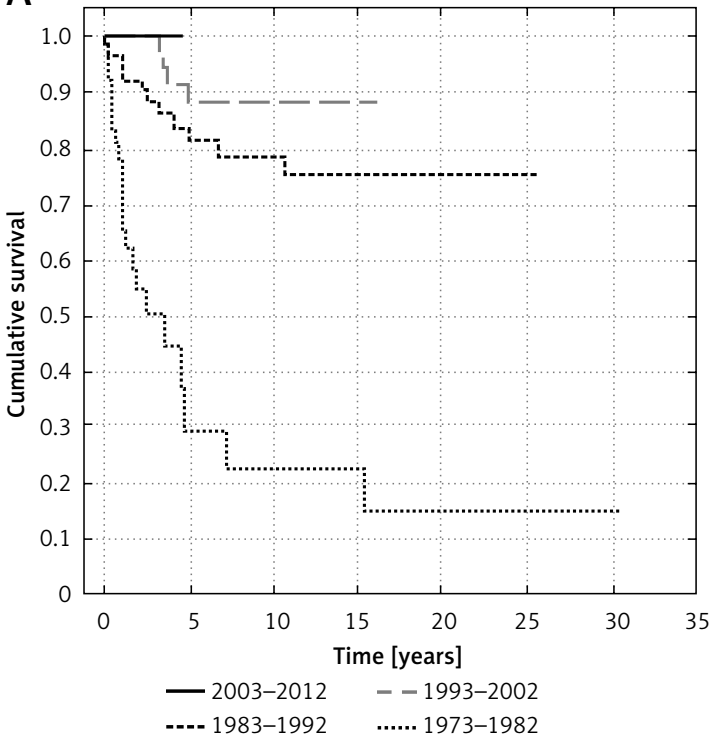

B

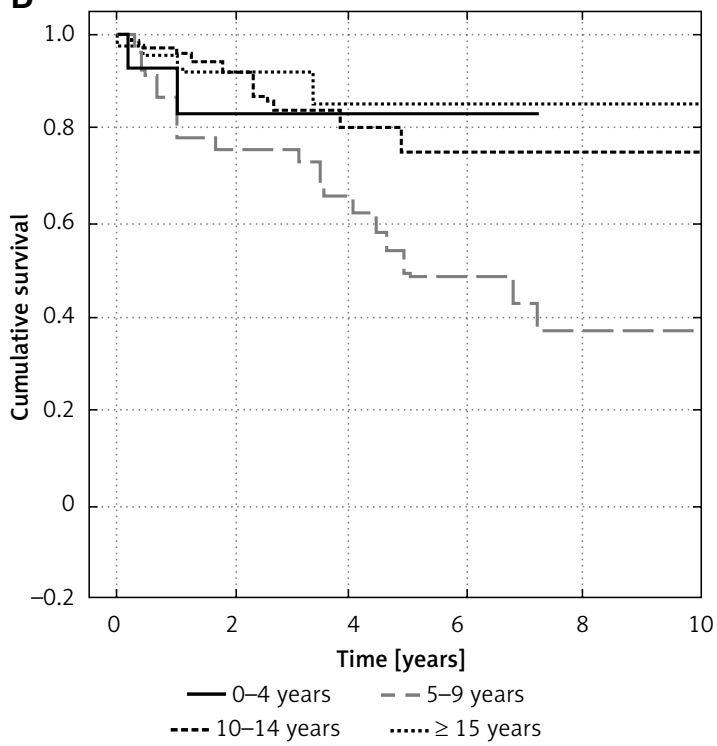

Figure 2. Survival according to Kaplan-Meier analysis. A - comparison of survival in decades 1973-1982, 19831992, 1993-2002, 2003-2012, B - comparison of survival in 4 age groups (age at initiation of RRT): 0-4 years, 5-9 years, $10-14$ years, $\geq 15$ years

neal dialysis (including 5 with CAPD and 2 with APD). The HD was the RRT modality used for the longest time in 30 of these children, and chronic peritoneal dialysis was used for the longest time in 6 children.

The most common cause of death according to the pediatric ERA-EDTA registry classification both in the overall study population and in subsequent decades of the study period were cardiovascular problems, found in 13/36 (36.1\%) children and significantly more frequent $(p<0.01)$ than such causes as hyperkalemia (ERA-EDTA group I), infections (group V), cancer (group VI), and miscellaneous causes (group VII). The second most common cause of death was sudden cardiac death, identified in $6(16.7 \%)$ children. Cancer was the cause of death of 3 children (Wilms' tumor in 1 child, and non-Hodgkin lymphoma in 2 children). We did not find significant differences in the rate of specific causes of death in relation to the RRT modality used. Among children below 5 years of age, the most common cause of death was cancer (in 2 children, 28.6\%), and cardiovascular problems were the most common causes of mortality in the age groups of $5-9$ and $10-14$ years (43.8\% and $41.7 \%$, respectively).

\section{Risk factors for mortality}

Comparison of clinical and biochemical characteristics of survivors and non-survivors of RRT in 1973-2002 showed that the mean age at the initiation of RRT was significantly lower $(p<0.01)$ in those children who died. Mean time from the diagnosis of CKD and total duration of RRT did not differ between groups (Table III). We found no significant differences in renal function parameters at the time of RRT initiation, while residual diuresis was significantly higher $(p<0.01)$ among survivors. Residual diuresis was preserved before the initiation of RRT in $76 \%$ of children who died and $89.7 \%$ of children who survived ( $p=N S$ ), and at the end of follow-up in $17.4 \%$ of children who died and $54.95 \%$ of children who survived $(p<0.01$ ). Cox proportional hazard model analysis showed that residual diuresis at the time of RRT initiation was a significant predictor of mortality (relative risk (RR) 0.99; 95\% confidence interval (Cl): 0.991.00). Mean $\mathrm{Hb}$ level was significantly lower ( $p<$ 0.0001 ) in non-survivors compared to survivors. $\mathrm{Hb}$ level both at the time of RRT initiation and during RRT was shown to be a significant prognostic factor $(R R=0.72,95 \% \mathrm{Cl}: 0.57-0.9$; and $R R=$ $0.65,95 \% \mathrm{Cl}: 0.53-0.78$, respectively). Treatment with ESA was used significantly less frequently in non-survivors compared to survivors both before RRT initiation (5.56\% vs. $31.36 \% ; p<0.05)$ and during RRT (19.44\% vs. $67.8 \% ; p<0.0001)$.

Children who died were characterized by lower levels of TP, Alb, and Chol at the beginning and throughout the treatment period. Hypoalbuminemia was found significantly more frequently ( $p<$ 0.01 ) in non-survivors compared to survivors both at the initiation of RRT ( $61.9 \%$ vs. $47.46 \%)$ and at the end of follow-up (72.22\% vs. $38.98 \%)$. We also found that serum Alb level at the end of follow-up $<3.5 \mathrm{~g} / \mathrm{dl}$ and TG level > $150 \mathrm{mg} / \mathrm{dl}$ were associated with increased risk of mortality $(R R=0.13$, 95\% Cl: $0.02-0.74$; and $\mathrm{RR}=6.21,95 \% \mathrm{Cl}: 1.57-$ 24.57 , respectively). 
Table II. Causes of death and comorbidity

\begin{tabular}{|c|c|c|c|c|c|c|c|c|}
\hline Patient no. & & & imary renal diseases & Comorbidity & $\begin{array}{l}\text { Age at } \\
\text { start } \\
\text { of RRT }\end{array}$ & $\begin{array}{l}\text { Age at } \\
\text { death }\end{array}$ & & Cause of death \\
\hline \multirow[t]{20}{*}{$\begin{array}{l}\text { Decade } \\
1973-1983\end{array}$} & 1 & 1 & FSGS & $\begin{array}{c}\text { Developmental } \\
\text { delay }\end{array}$ & 3 & 3.19 & \multirow[t]{2}{*}{ III } & $\begin{array}{c}\text { Heart } \\
\text { insufficiency }\end{array}$ \\
\hline & 2 & & Crescentic GN & - & 7.99 & 8.32 & & $\begin{array}{l}\text { Uremic } \\
\text { cardiomyopathy }\end{array}$ \\
\hline & 3 & & $\begin{array}{c}\text { Membranoproliferative } \\
\text { GN }\end{array}$ & - & 14.96 & 30.4 & \multirow[t]{2}{*}{ V } & $\begin{array}{c}\text { Pneumonia } \\
\text { (Candida } \\
\text { albicans) }\end{array}$ \\
\hline & 4 & & End stage GN & Heart insufficiency & 4.39 & 11.58 & & $\begin{array}{c}\text { Sepsis } \\
(P . \text { aeruginosa })\end{array}$ \\
\hline & 5 & & Rapidly progressive GN & - & 11.66 & 14.1 & VII & $\begin{array}{c}\text { Hemolysis during } \\
\text { HD }\end{array}$ \\
\hline & 6 & & End-stage GN & - & 4.73 & 5.73 & \multirow[t]{3}{*}{ VIII } & Unknown \\
\hline & 7 & & Rapidly progressive GN & - & 6.96 & 7.96 & & Unknown \\
\hline & 8 & & End-stage GN & - & 4.87 & 5.54 & & Unknown \\
\hline & 9 & \multirow[t]{2}{*}{ II } & Reflux nephropathy & - & 7.03 & 10.5 & II & Cardiac arrest \\
\hline & 10 & & $\begin{array}{l}\text { Posterior urethral } \\
\text { valves }\end{array}$ & Epilepsy & 9.26 & 11.07 & III & $\begin{array}{c}\text { Uremic } \\
\text { cardiomyopathy }\end{array}$ \\
\hline & 11 & \multirow[t]{2}{*}{ III } & Nephronophthisis & - & 14.73 & 15.73 & III & $\begin{array}{c}\text { Heart } \\
\text { insufficiency }\end{array}$ \\
\hline & 12 & & Nephronophthisis & Hepatitis & 8.47 & 12.9 & VII & Liver cirrhosis \\
\hline & 13 & IV & Renal hypoplasia & - & 10.56 & 11.8 & \multirow[t]{3}{*}{ III } & $\begin{array}{c}\text { Heart } \\
\text { insufficiency }\end{array}$ \\
\hline & 14 & & Oligomeganephronia & - & 10.74 & 10.98 & & $\begin{array}{c}\text { Heart } \\
\text { insufficiency }\end{array}$ \\
\hline & 15 & & Dysplasia & Heart insufficiency & 5.02 & 5.73 & & $\begin{array}{c}\text { Heart } \\
\text { insufficiency }\end{array}$ \\
\hline & 16 & & Hypoplasia & - & 8.64 & 10.30 & VII & $\begin{array}{l}\text { Pulmonary } \\
\text { embolism }\end{array}$ \\
\hline & 17 & VII & H-Sch purpura & - & 7.62 & 12.25 & II & Cardiac arrest \\
\hline & 18 & & Amyloidosis & JIA & 7.48 & 7.8 & \multirow[t]{3}{*}{ VIII } & Unknown \\
\hline & 19 & & H-Sch purpura & - & 12.34 & 13.4 & & Unknown \\
\hline & 20 & & $\mathrm{H}$-Sch purpura & - & 16.01 & 16.4 & & Unknown \\
\hline \multirow[t]{12}{*}{ 1983-1992 } & 21 & II & $\begin{array}{l}\text { Posterior urethral } \\
\text { valves }\end{array}$ & - & 5.83 & 12.62 & III & $\begin{array}{c}\text { Heart } \\
\text { insufficiency }\end{array}$ \\
\hline & 22 & IV & Dysplastic kidneys & Jeune syndrome & 6.66 & 9.79 & II & Cardiac arrest \\
\hline & 23 & V & HUS & - & 8.38 & 18.96 & III & $\begin{array}{c}\text { Heart } \\
\text { insufficiency }\end{array}$ \\
\hline & 24 & & HUS & - & 11.01 & 19.47 & V & Sepsis \\
\hline & 25 & VI & Nephrocalcinosis & - & 4.67 & 8.69 & 1 & Hyperpotassemia \\
\hline & 26 & VII & Injury of single kidney & - & 10.87 & 11.22 & \multirow[t]{2}{*}{ II } & Cardiac arrest \\
\hline & 27 & & Goodpasture syndrome & - & 8.44 & 9.4 & & Cardiac arrest \\
\hline & 28 & & Amyloidosis & Severe hypertension & 8.44 & 9.51 & III & $\begin{array}{c}\text { Heart } \\
\text { insufficiency }\end{array}$ \\
\hline & 29 & & Wilms tumor & Wilms tumor & 5.43 & 6.43 & \multirow[t]{2}{*}{ VI } & Neoplasm \\
\hline & 30 & & $\mathrm{NHL}$ & $\mathrm{NHL}$ & 4.68 & 4.97 & & Neoplasm \\
\hline & 31 & & Amyloidosis & JIA & 14.9 & 14.95 & VII & Liver insufficiency \\
\hline & 32 & VIII & Unknown & - & 11.58 & 14.12 & III & Pericarditis \\
\hline
\end{tabular}


Table II. Cont.

\begin{tabular}{|c|c|c|c|c|c|c|c|c|}
\hline Patient no. & & & ary renal diseases & Comorbidity & $\begin{array}{l}\text { Age at } \\
\text { start } \\
\text { of RRT }\end{array}$ & $\begin{array}{l}\text { Age at } \\
\text { death }\end{array}$ & & Cause of death \\
\hline \multirow[t]{4}{*}{ 1993-2002 } & 33 & VII & Amyloidosis & $\begin{array}{c}\text { JIA, liver } \\
\text { insufficiency }\end{array}$ & 14.67 & 18.02 & ॥ & Cardiac arrest \\
\hline & 34 & & Amyloidosis & $\begin{array}{c}\text { Tuberculosis, } \\
\text { epilepsy }\end{array}$ & 7.56 & 11.07 & III & $\begin{array}{c}\text { Heart } \\
\text { insufficiency }\end{array}$ \\
\hline & 35 & & Amyloidosis & $J I A$ & 13.05 & 16.81 & & $\begin{array}{c}\text { Heart } \\
\text { insufficiency }\end{array}$ \\
\hline & 36 & & Cisplatin toxicity & NHL-pancytopenia & 9.12 & 13.98 & $\mathrm{VI}$ & Neoplasm \\
\hline
\end{tabular}

H-Sch - Henoch-Schönlein purpura, JIA - juvenile idiopathic arthritis, GN - glomerulonephritis, NHL - non-Hodgkin lymphoma, HUS hemolytic uremic syndrome, FSGS - focal segmental glomerulosclerosis.

Table III. Comparison of clinical and biochemical parameters in survivors and non-survivors treated with RRT in years 1973-2002 (decade I, II, III)

\begin{tabular}{|c|c|c|c|c|}
\hline \multicolumn{2}{|l|}{ Parameter } & $\begin{array}{c}\text { Non-survivors } \\
N=36\end{array}$ & $\begin{array}{c}\text { Survivors } \\
N=118\end{array}$ & $P$-value \\
\hline \multicolumn{2}{|l|}{$\begin{array}{l}\text { Time from CRF diagnosis to RRT } \\
\text { initiation [years] }\end{array}$} & $2.2(0.02-16)$ & $3.5(0-17.4)$ & NS \\
\hline \multicolumn{2}{|l|}{ Age at initiation of RRT [years] } & $8.94 \pm 3.5$ & $11.2 \pm 4.28$ & $<0.1$ \\
\hline \multicolumn{2}{|l|}{ Duration of RRT [years] ${ }^{* *}$} & $1.5(0.1-15.5)$ & $1.9(0.1-16.3)$ & NS \\
\hline \multirow[t]{2}{*}{ Serum urea $[\mathrm{mg} / \mathrm{dl}]^{*}$} & 1 & $187.6 \pm 59.5$ & $170.4 \pm 56.1$ & NS \\
\hline & $E$ & $150.1 \pm 69.4$ & $132.1 \pm 41.0$ & NS \\
\hline \multirow[t]{2}{*}{ Serum creatinine $[\mathrm{mg} / \mathrm{dl}]^{*}$} & 1 & $7.4 \pm 3.3$ & $7.3 \pm 2.9$ & NS \\
\hline & $\mathrm{E}$ & $6.5 \pm 2.7$ & $9.0 \pm 3.1$ & $<0.01$ \\
\hline GFR $\left[\mathrm{ml} / \mathrm{min} / 1.73 \mathrm{~m}^{2}\right]^{*}$ & 1 & $8.5 \pm 7.8$ & $10.8 \pm 6.0$ & NS \\
\hline \multirow[t]{2}{*}{ Residual diuresis $\left[\mathrm{ml} / \mathrm{m}^{2} / \mathrm{day}\right]^{\star *}$} & 1 & $416.1(0.0-1969.5)$ & $828.7(0.0-4109.9)$ & $<0.01$ \\
\hline & $\mathrm{E}$ & $0.0(0.0-898.6)$ & $0.0(0.0-3492.1)$ & NS \\
\hline \multirow[t]{2}{*}{ Hemoglobin [g/dl] } & 1 & $7.7 \pm 2.1$ & $9.1 \pm 1.5$ & $<0.0001$ \\
\hline & $E$ & $7.9 \pm 2.8$ & $9.6 \pm 1.9$ & $<0.0001$ \\
\hline \multirow{2}{*}{$\begin{array}{l}\text { Number of children treated } \\
\text { with ESA (\%) }\end{array}$} & 1 & $2(5.6)$ & $37(31.4)$ & $<0.05$ \\
\hline & $\mathrm{E}$ & $7(19.4)$ & $80(67.8)$ & $<0.0001$ \\
\hline \multirow[t]{2}{*}{ Serum total protein $[\mathrm{g} / \mathrm{dl}]^{*}$} & 1 & $5.6 \pm 1.2$ & $6.3 \pm 0.8$ & $<0.001$ \\
\hline & $\mathrm{E}$ & $5.7 \pm 0.9$ & $6.5 \pm 0.8$ & $<0.001$ \\
\hline \multirow[t]{2}{*}{ Serum albumin $[\mathrm{g} / \mathrm{dl}]^{*}$} & 1 & $3.3 \pm 2.8$ & $3.5 \pm 0.6$ & NS \\
\hline & $E$ & $3.3 \pm 0.7$ & $3.6 \pm 0.6$ & $<0.05$ \\
\hline \multirow[t]{2}{*}{$\mathrm{BMI}(\mathrm{SDS})^{\star \star}$} & 1 & $-0.4(-2.7 ; 4.9)$ & $-0.8(-5.7 ; 10.2)$ & NS \\
\hline & $\mathrm{E}$ & $-1.6(-3.6 ; 2.8)$ & $-1.0(-3.3 ; 11.6)$ & $<0.05$ \\
\hline \multirow[t]{2}{*}{ Serum cholesterol $[\mathrm{mg} / \mathrm{dll}]^{*}$} & 1 & $200.0(95.0-520.0)$ & $180.0(108.0-580.0)$ & NS \\
\hline & $\mathrm{E}$ & $140.0(81.0-345.0)$ & $172.0(25.0-426.3)$ & $<0.01$ \\
\hline \multirow[t]{2}{*}{ Serum triglycerides $[\mathrm{mg} / \mathrm{dl}]^{*}$} & 1 & $230.0(79.0-535.0)$ & $179.0(34.0-822.0)$ & NS \\
\hline & E & $178.0(101.0-482.0)$ & $163.5(34.0-565.0)$ & NS \\
\hline \multirow[t]{2}{*}{ Serum Ca $[\mathrm{mg} / \mathrm{dl}]$} & I & $8.3 \pm 1.7$ & $8.6 \pm 1.1$ & NS \\
\hline & E & $9.2 \pm 1.0$ & $9.3 \pm 1.1$ & NS \\
\hline \multirow[t]{2}{*}{ Serum $P[\mathrm{mg} / \mathrm{dl}]$} & I & $6.5 \pm 2.6$ & $5.6 \pm 1.8$ & $<0.05$ \\
\hline & E & $5.4 \pm 2.4$ & $5.9 \pm 1.8$ & NS \\
\hline
\end{tabular}

I- initiation of RRT, E- end of RRT in our unit. 
Hypertension at the time of RRT initiation was diagnosed in $85.7 \%$ of children who died compared to $70.3 \%$ of the survivors ( $p=N S$ ). However, at the end of follow-up it was significantly more common $(p<0.05)$ among those who died compared to those who survived ( $80.95 \%$ vs. $58.4 \%$ ). Left ventricular hypertrophy by electrocardiography and/or echocardiography was found significantly more frequently $(p<0.05)$ among non-survivors (80.9\%) compared to survivors (51.2\%).

\section{Discussion}

Our study summarizes outcomes in 208 children with stage 5 chronic kidney disease who were treated with RRT in the oldest pediatric dialysis unit in Poland. In the successive decades of the follow-up period, we observed a decreasing rate of glomerulonephritis and an increasing rate of renal hypo-/dysplasia and obstructive uropathy as the causes of CKD. Our findings are consistent with other registry data regarding the most common causes of ESRD in the pediatric population $[6,8-12]$ that show similar changes in the etiology of ESRD, attributed to diagnostic and therapeutic advances in this area [13]. The high rate of glomerulonephritis in the 1970s might have resulted from the lack of effective immunosuppressive therapy regimens for the treatment of severe glomerulonephritis at that time. Similar observations were made in Australian (ANZDATA) and American (USRDS) registries, which showed that glomerulonephritis was the most common cause of ESRD in children in the 1970s and 1980s [13, 14].

The choice of initial RRT method in the analyzed children was related to the availability of various modalities during the study period. With current wide availability of all RRT modalities, this decision is usually based on the preference of the patient's family and the advice of a nephrologist, depending on such factors as patient age, distance from the place of living to the dialysis therapy unit, and other individual characteristics. In the last decade of the study period, the proportions of patients treated with HD and peritoneal dialysis were similar to other data from Poland, Europe, and elsewhere $[6,8,11,15]$. In 2007, HD was the initial RRT modality in $33 \%$ of children in Poland, peritoneal dialysis was initially used in $54 \%$ of children, and $13 \%$ of children received a preemptive renal transplant [11]. According to the 2008 ESPN/ERA-EDTA data, HD was the initial RRT modality in $36.1 \%$ of children in Europe, peritoneal dialysis was initially used in $48.8 \%$ of children, and preemptive renal transplantation was performed in $15.1 \%$ of children [16], and in the ANZDATA registry (2008) these proportions were $46 \%, 38 \%$ and $16 \%$, respectively [17]. In our study group, preemptive renal transplantation was performed in only 4 of 99 children who underwent kidney transplantation, and the first such procedure was performed in 1995 as the first preemptive renal transplantation in Poland. The rate of preemptive renal transplantation in our study group was thus low, which is consistent with the current situation in the whole country [11].

In our study group, $17.31 \%$ of children died, and cardiovascular problems were the most common cause of death. These findings are consistent with results reported by other authors [4, 18]. Cardiovascular and infectious complications are currently the major cause of death among children with ESRD in many registries $[8,11,12,14]$. The most common causes of death among children treated with RRT in Poland in 2006 included in fectious complications (30\%), heart failure (22\%), and sudden death (22\%) [11]. In our study, infectious complications accounted for only $8.9 \%$ of deaths, similarly to findings in a Polish population reported by Litwin et al. [19].

Most deaths in our study population occurred in the first decade of the activity of our unit, when most patients were referred late, in the terminal phase of renal failure. Mortality rates in the first two decades (1973-1982 and 1983-1992) were high, while the mortality rate in 1993-2002 was comparable to data reported elsewhere for similar periods $[1,20]$. Reiss et al. reported a mortality rate of 6.6 per 100 patient-years in 1969-1978, 2.5 per 100 patient-years in 1979-1988, and 2.9 per 100 patient-years in 1989-1992 [2]. Currently, the mortality rate among children treated with chronic dialysis in Poland is 1.8 per 100 patient-years [21]. Overall mortality in our study population was similar to results reported for similar follow-up periods in the UK [22], Italy [20], and also in another Polish study which showed that 3-year survival was $71 \%$ among children who began RRT in 1983-1991 and 86\% among those who began RRT in 1983-2000 [18]

Our observation of the highest mortality among those children in whom RRT was initiated below 5 years of age is consistent with results reported by other authors [4, 12, 22].

Cox proportional hazard model analysis showed that lower residual diuresis at the time of RRT initiation was associated with higher mortality risk. These findings are consistent with other studies [22-24]. Benefits of preserved residual renal function include less hypertension, lower prevalence of left ventricular hypertrophy, and improved control of water and electrolyte abnormalities. In addition, preserved residual renal function was found to correlate with better parameters of protein and lipid balance and reduced severity of anemia [25]. In our study group, $\mathrm{Hb}$ level had a significant effect on the risk of death, 
and erythropoietin treatment was used significantly more frequently in survivors compared to non-survivors. This observation highlights the importance of appropriate treatment of anemia in children with ESRD and emphasize the role of erythropoiesis stimulating agents in improving prognosis in patients with chronic kidney disease [26]. According to the KDIGO recommendations, in all pediatric CKD patients receiving ESA therapy, $\mathrm{Hb}$ concentration should be in the range of 11.0 to $12.0 \mathrm{~g} / \mathrm{dl}$ (110 to $120 \mathrm{~g} / \mathrm{l}$ ) [27].

Both at the initiation of RRT and at the end of follow-up, children who died were characterized by more frequent hypoalbuminemia, which is a risk factor for mortality. Studies performed in the recent years showed significant correlations between low serum albumin level and other indicators of malnutrition and morbidity and mortality among patients with ESRD [28, 29]. Wong et al. reported that mortality risk in children with ESRD and a serum albumin level below $3.5 \mathrm{~g} / \mathrm{dl}$ was $90 \%$ higher compared to those with an albumin level $>3.5 \mathrm{~g} /$ dl [29]. In our study, TG level > $150 \mathrm{mg} / \mathrm{dl}$ during dialysis therapy was associated with an increased risk of mortality $(\mathrm{RR}=6.21,95 \% \mathrm{Cl}: 1.57-24.57$, $p<0.01)$. Shlipak et al. also found an association between hypertriglyceridemia and the risk of cardiovascular complications and death [30].

Hypertension and left ventricular hypertrophy in the study group were significantly more frequent in non-survivors than survivors. These observations are in agreement with the results reported by Litwin et al. [19], showing that $70 \%$ of deaths among children on chronic dialysis were due to cardiovascular causes. In that group of patients frequency of hypertension was greater in non-survivors and the number of hypotensive drugs taken by patients who died was significantly greater in comparison to the survivors $(1.86 \pm 1.06$ vs. $0.97 \pm 0.81)$, which indicated difficulties with the control of hypertension in non-survivors. Franczyk-Skóra et al. in a group of 118 patients with CKD found that the stage of renal failure was associated with a significant increase in left ventricle mass and highlighted the importance of early identification of factors involved to prevent the devastating process of left ventricle hypertrophy [31].

In our group, children with miscellaneous renal disease as the cause of CKD were characterized by higher mortality. Risk of death is known to be increased in patients with ESRD due to systemic disease, secondary glomerulopathies, vasculitis, and metabolic disease, and lower in patients with primary glomerulopathies, renal hypo-/dysplasia, and pyelonephritis [4, 22].

Of note, significant concomitant diseases were present in all non-survivors who began dialysis therapy in 1993-2002. Concomitant diseases have a significant negative effect on prognosis, particularly in younger children [20, 22]. Continued high mortality among children with ESRD is thought to be mostly related to the fact that RRT is now initiated in children with more severe concomitant diseases who generally are in a worse clinical condition compared to those treated in the previous years. Shroff et al. noted a 7.5-fold increase in mortality risk among patients with concomitant extrarenal diseases [22].

The limitation of our study is its retrospective character and the fact that the study population is from a single center. The shortage of precise information in historical medical data prevented us from analyzing the influence of development of different dialysis techniques (type of dialyzers, dialysates) on survival improvement. The influence of evolution of hemodialysis (miniaturization of dialyzers, reduced frequency of hemorrhagic complications), peritoneal dialysis (replacement of acetate dialysate with bicarbonate-based dialysate) and transplantology (evolution in immunosuppressive therapy) has a fundamental role in the improved survival of children with end stage renal disease.

In conclusion, our study summarizes outcomes in children treated during a 40-year follow-up period in a single pediatric dialysis unit in an Eastern European country. We found a significant improvement in prognosis among children with CKD 5 in 1973-2012, and identified predictors of mortality that included young age at initiation of RRT, low residual diuresis at the time of RRT initiation, anemia, and hypertriglyceridemia.

\section{Conflict of interest}

The authors declare no conflict of interest.

\section{References}

1. McDonald S, Craig JC; Australian and New Zealand Paediatric Nephrology Association. Long-term survival of children with end-stage renal disease. $\mathrm{N}$ Eng J Med 2004; 350: 2654-62.

2. Reiss U, Wingen AM, Scharer K. Mortality trends in pediatric patients with chronic renal failure. Pediatr Nephrol 1996; 10: 41-5.

3. Van der Heijden BJ, van Dijk PC, Verrier-Jones K, Jager KJ, Briggs JD. Renal replacement therapy in children: data from 12 registries in Europe. Pediatr Nephrol 2004; 19: 213-21.

4. Groothoff JW, Gruppen MP, Offringa M, et al. Mortality and causes of death of end-stage renal disease in children: a Dutch kohort study. Kidney Int 2002; 61: 621-9.

5. NAPRTCS:2005 Annual Report, Rockville, MD, EMMES.2005. Available at: http://www.emmes.com/study/ ped/annlrept/annlrept.html. Accessed 27.05.2015

6. NAPRTCS:2008 Annual Report, Rockville, MD, EMMES. 2008. Available at: http://www.emmes.com/study/ped/ annlrept/annlrept.html. Accessed 27.05.2015. 
7. Dzieje I Wydziału Lekarskiego Akademii Medycznej w Warszawie (1809-2006). Krawczyk M (ed.). Lublin 2008; 876-88, 1394-408.

8. Esbjorner E, Berg U, Hansson S. Epidemiology of chronic renal failure in children: a report from Sweden 18961994. Pediatr Nephrol 1997; 11: 438-42

9. Ardissino G, Dacco V, Testa S, et al. Epidemiology of chronic renal failure in children: data from the ItalKid Project. Pediatrics 2003; 111: e382-7.

10. Ansell D, Feehally J, Fogarty D. UK Renal Registry 2009. $12^{\text {th }}$ Annual Report of the Renal Association. Chapter 14: Demography of the UK Pediatric Renal Replacement Therapy population in 2008. Nephron Clin Pract 2010; 115 (Suppl. 1): 282-8.

11. Żurowska A, Zagożdżon I, Bałasz-Chmielewska I. Dializoterapia u dzieci. In: Rutkowski B, LichodziejewskaNiemierko M, Grenda R (eds.). Raport o stanie leczenia nerkozastępczego w Polsce - 2007 [Polish]. Drukonsul, Gdańsk 2009; 59-63.

12. Miklovicova D, Cornelissen M, Cransberg K, Groothoff JW, Dedik L, Schroeder CH. Etiology and epidemiology of end-stage renal disease in Dutch children 19872001. Pediatr Nephrol 2005; 20: 1136-42.

13. Orr NI, McDonald S, McTaggart SJ, Henning P, Craig JC. Frequency, etiology and treatment of childhood endstage kidney disease in Australia and New Zealand. Pediatr Nephrol 2009; 24: 1719-26.

14. US Renal Data System (USRDS) (2008) Annual Data Report: Atlas of Chronic Kidney Disease and End-Stage Renal Disease in the United States, National Institutes of Health, National Institute of Diabetes and Digestive and Kidney Diseases, Bethesda, MD. Available: www.USRDS. org. Accessed at: 27.05.2015.

15. Van Stralen KJ, Tizard EJ, Verrina E, Schaefer F, Jager KJ. Demographics of pediatric renal replacement therapy in Europe: 2007 Annual Report of the ESPN/ERA-EDTA registry. Pediatr Nephrol 2010; 25: 1379-82.

16. ESPN/ERA-EDTA Registry 2008 - Registry of the European Society for Pediatric Nephrology. Available at: http:// www.espn-reg.org. Accessed 27.05.2015.

17. Mc Taggart S, Kennedy S, McDonald S, Henning $P$ Dent H. Pediatric Report - ANZDATA 2008 - Australia and New Zealand Dialysis and Transplant Registry. Available at: http: anzdata.org.au/v1/report_2008.html. Accessed at: 27.05.2015.

18. Żurowska A. Dializa otrzewnowa. Optymalizacja metody oraz jej rola w leczeniu nerkozastępczym u dzieci [Polish]. Annales Academiae Medicae Gedanensis 2002; XXXII Suppl: 9-97.

19. Litwin M, Grenda R, Prokurat S, et al. Patient survival and causes of death on hemodialysis and peritoneal dialysis - single center study. Pediatr Nephrol 2001; 16: 996-1001.

20. Verrina E, Edefonti A, Gianoglio B, et al. A multicenter experience on patient survival in children on chronic dialysis. Pediatr Nephrol 2004; 19: 82-90.

21. Żurowska A, Zwolińska D. Leczenie nerkozastępcze u dzieci i młodzieży - odrębność i skala zjawiska [Polish]. Forum Nefrol 2010; 3: 57-62.

22. Shroff R, Rees L, Trompeter RI, Hutchinson C, Ledermann S. Long-term outcome of chronic dialysis in children. Pediatr Nephrol 2006; 21: 257-64.

23. Shemin D, Bostom AG, Laliberty P, Dworkin LD. Residual renal function and mortality risk in hemodialysis patients. Am J Kidney Dis 2001; 38: 85-90.

24. Wang AY, Woo J, Wang M, et al. Important differentiation of factors that predict outcome in peritoneal dialysis patients with different degrees of residual renal func tion. Nephrol Dial Transplant 2005; 20: 396-403.

25. Marron B, Remon C, Perez-Fontan M, Quiros P, Ortiz A. Benefits of preserving residual renal function in peritoneal dialysis. Kidney Int 2008; 73: S42-51.

26. Warady BA, Ho M. Morbidity and mortality in children with anemia at initiation of dialysis. Pediatr Nephrol 2003; 18: 1055-62.

27. KDIGO Clinical Practice Guideline for anemia in chronic kidney disease. Kidney Int 2012; Suppl. 2: 331-5.

28. Kalantar-Zadech K, Ikizler TA, Block G, Avram MM, Kopple JD. Malnutrition - inflammation complex syndrome in dialysis patients: causes and consequences. Am J Kidney Dis 2003; 42: 864-81.

29. Wong CS, Hingorani S, Gillen DL, et al. Hypoalbumin emia and risk of death in pediatric patients with endstage renal disease. Kidney Int 2002; 61: 630-7.

30. Shlipak MG, Fried LF, Cushman M, et al. Cardiovascular mortality risk in chronic kidney disease. Comparison of traditional and novel risk factors. JAMA 2005; 293: 1737-45.

31. Franczyk-Skóra B, Gluba A, Olszewski R, Banach M, Rysz J. Heart function disturbances in chronic kidney disease - echocardiographic indices. Arch Med Sci 2014; 10: 1109-16. 